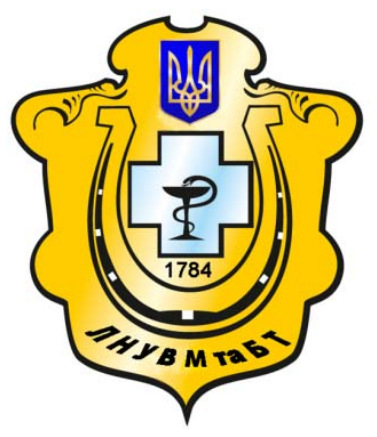

Науковий вісник Львівського національного університету ветеринарної медицини та біотехнологій імені С.3. Гжицького

Scientific Messenger of Lviv National University of Veterinary Medicine and Biotechnologies named after S.Z. Gzhytskyj

doi:10.15421/nvlvet7602

ISSN 2519-2701 print

ISSN 2518-1327 online

http://nvlvet.com.ua/

UDC 158.943:338.26

\title{
Information influence on management decisions
}

\author{
B. Batyuk \\ bbbatyk@gmail.com \\ Lviv national university of veterinary medicine and biotechnologies named after S. Gzhytskyj, \\ Pekarska Str., 50, Lviv, 79010, Ukraine;
}

The basic task manipulation in the management environment, which is focused on the impact of the opinion of the persons involved to achieve a certain driven result are revealed. The investigation of certain results for manipulation of information in the administration that are designed to show the most widespread cases of influence.

The study proved that the management in terms of manipulation of information is a creative process of selecting from the list of possible alternatives to a single decision that is taken for execution.

Specifics of management in terms of manipulation of information and uncertainty is that it is always an act of volition, social action, which expresses not only the needs and interests of individuals and reflects the interests of the organization, but also can realize the interests of the team as a whole that would not violate the etiquette and were accepted norms of human life.

Key words: influence, information, decision management, manager, team, method, economy, technology.

\section{Інформаційний вплив на прийняття управлінських рішень}

\author{
Б.Б. Батюк \\ bbbatyk@gmail.com
}

Львівський національний університет ветеринарної медицини та біотехнологій імені С.3. Гжицького, вул. Пекарська, 50, м. Львів, 79010, Украӥна;

Розкрито основні завдання маніпулящії в управлінському середовищі, які иілеспрямовані на вплив думку задіяних осіб для досягнення визначеного керованого результату. Здійснено дослідження окремих результатів шьодо маніпулювання інформацією під час управління, що покликані показати найбільш поширенні випадки впливу.

В результаті дослідження доведено, що прочес управління в умовах маніпулювання інформацією є творчим процесом вибору із переліку можливих альтернатив єдиного рішення, яке приймається до виконання.

Ключові слова: вплив, інформація, рішення, управління, керівник, колектив, метод, економіка, технологія.

\section{Информационное воздействие на принятие управленческих решений}

\author{
Б.Б. Батюк \\ bbbatyk@gmail.com
}

Львовский национальный университет ветеринарной медиичны и биотехнологий имени С.3. Гюицкого,
ул. Пекарская, 50, г. Львов, 79010, Украина;

Раскрыты основные задачи манипуляции в управленческой среде, целенаправленные на воздействие мнения задействованных лии для достижения определенного управляемого результата. Проведено исследование отдельных результатов по манипулирования информацией при управлении, призванные показать наиболее распространенные случаи воздействия.

Citation:

Batyuk, B. (2017). Information influence on management decisions. Scientific Messenger LNUVMBT named after S.Z. Gzhytskyj, 19(76), 10-14. 
В результате исследования доказано, что прочесс управления в условиях манипулирования информацией является творческим процессом выбора из перечня возможных альтернатив единого решения, которое принимается к исполнению.

Ключевые слова: влияние, манипуляция, информация, решения, управление, руководитель, коллектив, метод, экономика, технология.

\section{Formulation of the problem}

Problem, according to The American Heritage Dictionary, is «a question or situation that presents uncertainly, perplexity, or difficulty». The problem of manipulation is very important in our modern world. Some manipulator lives in every person and fights for existence in these current conditions. Modern manipulator develops and constantly improves himself. He also seeks to understand the secrets of human nature in order to better control the others. Some scholars (Borovs'ka, 2012) believe that the manipulators are not born they are from childhood. Because all children know how to use crying to manipulate their parents. And this is not a simple «little» understanding of how to care for a young baby by unexperienced parents.

Perfected technics of influence on motivation of actions and human's behavior - «nonviolent coercion» are developed today. Peoples' manipulation against their will, but with their consent for a small part of society is implemented every time. The information, which is an instrument of power over people as one of the means of social control is constantly used for this purpose.

As a result of qualitative changes, manipulation has come out to the forefront. Now it plays a determining role in social processes.

The main task of manipulation in the management environment is to be focused on the influence on the minds of individuals to achieve a certain driven result (Batyuk, 2014). However, the manipulation may be accompanied not only by positive goals, but also negative. That is why the manager or the group always try to use the mechanisms to achieve the purposes. Quite often distorted information is used during the conflict, competition, collision of opposite interests, etc.

\section{Analysis of recent research}

Everett Shostrom, Jay Haley, Eric Berne, William Glasser, Frederic Perls, Albert Ellis, Abraham Maslow, Erich Fromm, James Buhentalya and other scientists pay attention to the study of nature of information transfer and manipulation, causes and conditions of its appearance.

The modern term «manipulation» has got Latin roots, «manipulus»: manus - «hand» («manipulus» - «handful» (of «manus») and «ple» - «to fill» (Kulinich, 2006).

There are some scientific thoughts about the concept of the term «manipulation». According to the theory of William Glasser, a man is «irresponsible» and desperately needs to «pass the buck to others». According to the theory of Eric Berne, modern man is the man that «plays games» (Bern, 2003). Albert Ellis assures us that the man - a «person who is acting on the basis of illogical assumptions» (Jellis, 2002). Everett Shostrom considers that men are manipulators serving unreliable persons that seek to manage themselves and others, and treate people as things and not realise their falsity and non-viability. That is why a person needs such psychological care, which he/she understands and for whom benefit is obvious (Shostrom, 2003).

Frederick Perls believed that the main cause of the phenomenon of manipulation is in perpetual internal conflict between the human desire for independence and autonomy on the one hand, and the desire to find support in their external environment - on the other. Not trusting completely on their own, a man believes her salvation to rely on others. However, the man does not fully trust others, so he steps on a slippery slope manipulation to set the «others on a short lace». Then he could always control them and in such conditions, trusted them (Perlz et al., 1995).

French writer Luc de Klape de Vovenarh said, «Art to be pleased is the art of deception». Christian Johann Heinrich Heine said: «Anyone who wants to influence the crowd must have witch seasonings» (Kulinich, 2006). On this folk wisdom also specifies that the one who creates the wind, the storm can get.

Sidorenko E.V. gives an interesting definition, that manipulation is a deliberate and hidden motives of another person to experience certain conditions, decision making and impulse actions that are needed for initiator to achieve their goals (Sidorenko, 2002).

Sheinov V.P. believes that manipulation is a kind of psychological impact, whose skilful performance leads to the breach another person's intentions that do not coincide with his actual existing desires. It also gives metaphorical definition of manipulation «manipulation - is action aimed at «holding in the hands» another person, control which is produced so skillfully that it is seemed that he controls his behavior himself» (Shejnov, 2003).

Shulsky M.G. believes that the psychological manipulation is the process of using different tools and resources specific changes in human behavior or goals, desires, intentions, relationships, attitudes, mental states and other characteristics of his psychological impact in the subject, and which could not happen if the recipient knew in sufficient data concerning the situation, including which methods were used against him or for what purpose they were used (Shulskyi, 2016).

In view of the foregoing some unresolved issues of manipulative influence of information on the management process remains up to date.

The purpose of the article. The article presents the results of some research on the manipulation of information during management that help to show the most widespread cases of influence.

\section{Presentation of main material}

The basis of communicative converse is the ability to make contact with the person and keep business communication to a certain level. Skilled manipulator operates very delicately and in the communication 
process tries to create trust and to re-use information on his/her own. Thus preparatory stage is created and during it the manipulator fully adapts to the companion, using the technique of joining. As the manipulator can be head of the organization or leading managers who use this technology to look for common interests and views and create an atmosphere of openness and a favorable impression of themselves. In this situation they can copy the gestures of the communication partner, facial expressions, make similar poses, do anything to adjust themselves. Manipulation in communication is based on mental processes as the management - this is the choice of the available alternatives.

The logic of manipulators is obvious and regularity is clear: the larger the group, which should make an impact, the more universal «victims» have to be. Speciality and accurate focus of mass influence is possible when the organizer of the impact knows specific qualities of required groups of the population or groups of people. So the narrower is the intended group, the more accurate adjustment must be to its features. In cases when such adjustment for any reason is not making, universal provocatives appear again: the pride, the desire for pleasure, comfort, desire to have a family cosiness, career, fame these are quite available and understandable to most people values. If at the same time something does not work, it can be seen as inevitable starting salary for savings.

Modern methods of influence on the minds and actions of people, including: bribery, blackmail, threats of violence and violence had been using for a long time to target human behavior in the desired direction. However, we can not qualify this influence as manipulation. In many cases, a person who uses such methods does not matter whether the man believes in the rightness and justice him is forced to do. One who affected, in this case is only interested in one thing - to achieve his purpose. This influence is violent and forced.

Manager must resort to means of not violence but conviction that is based on deliberate deception or even better - suggestion. He has to create in the minds of his «victims» double illusion: first that it is this reality which he depicts, and secondly, that the response to this reality depends on the person who is the subject of manipulation.

In the process of manufacturing a man convinced that manipulation can bring not only benefit, but harm. Rather it can bring «good» to manipulators, and often can bring «hard times» for who are influenced by these manipulators. An example of this are the numerous pyramids. Let us recall how many times voters were wrong in policies which they expressed confidence. The word «manipulation» became negative again. More often we hear that someone is manipulating us, someone uses us, cheats us and so on.

There are many ways to influence the minds and actions of people, including: bribery, blackmail, threats of violence and violence itself. All that for a long time have been using to order human behavior in the desired direction. However, we can not qualify such influence as effect similar manipulate effect. In many cases, a person who uses such methods does not matter whether man believes in the right and justice that forced him to do or not. One who affected is only interested in one thing - to achieve his goals. This influence is really forced and violent.

Head must not use any violence and beliefs based on deliberate deception or even better - suggestion. He must create in the minds of his «victims» double illusion: first that it is this reality which he represents it, and secondly, that the response to this reality depends on the person who is the subject of manipulation.

Since the beginning of the production process man has convinced that manipulation can bring not only benefit, but harm. Exactly who manipulates has benefits, and those who are under influence, often has «hard times». The financial pyramids are an example of this. Let us recall how many times voters were wrong in policies to whom they have been expressed their voices. The word «manipulation» has become negative again. Increasingly we hear that someone is manipulating us, using us and diddling us etc.

Such named «method of accumulation» now acquired distribution. It provides integrated information flow and is rather difficult to understand even for analytics and for the community when such information becomes almost impossible task. An example of the method of preventing fragmentation may be reducing the quality perception of the facts as a result of supply so many news that manager is unable to classify them.

Incomplete submission of information is in partially its concealment (suppresssion). In this case, the informator simply does not tell the manager (the team) some fragments integral unit of integrated information flow that forms incorrect understanding of the situation as a result. The benefit to the sender is that in case of fact of distortion of information by the recipient the sender has ability to solve their problems.

Very effective approach for manipulating mass conscience - misinformation is wellknown in the field of business communication (Lazebna, 2011). Its essence lies in the fact that misinformation is mainly submitted at the time of the adoption of certain important decisions, and when it turns out the truth - the aim of misinformation will be already achieved. Refutation of misinformation in most cases remains undetected, and therefore it does not affect formed with the help of lies social and psychological factors.

Imaginative and artistic idea is created to manipulate and what is interesting nobody of manupulated persons feel anything and this is very advantageous in many respects. First, the manager gets an opportunity to flatter to manager (the team), appealing to his scholarship, for example: «Because you remember that ...». Second, history can show us many examples of almost in all life spheres. This method also helps in the design of historical metaphors which programmed an object of influence, as well as the necessary historical myths used in strategic perspective.

Distorted information can range from partial to complete lie distortion (manipulation of facts, different interpretations). The main advantage lies in the skillful selection of facts and their skilful commenting on or off by adding some little-known facts. In this way we can not only detect a nonexistent trend, but implement it as a real tendency. 
The great interest is in the usage of gossips in organizations in which managers provide much more value of whisper messages than for open published news (Perlz et al., 1995). This manager, who was given such news, considers himself as the owner of unique information. So this fact favors its affirmation. Overall, the situation of mystery and initiation helps fixing in memory of this message. Thus, reporting «the news in a whisper», will be achieved the highest effect of communication of information, while the recipient takes the responsibility for its accuracy. This concerns giving news as the «hidden links». Here is the principle of the expected deception: if people gossip - then there is reason for this.

Information received allegedly from «credible» but «anonymous sources» often is organized to conduct monitoring team thought about a specific list of questions (Lazebna, 2011). In case of a negative response team thought will be subjected to enhanced additional processing, to prepare it for the proper perception of the planned action in the organization (for instance, reducing staff units). If the reaction appears ultimately negative, it is always possible to refute the sensational information dissolving it in the form of gossips.

The method of «distraction» is used to distract the team from important but unprofitable manipulators of information by providing other information in the most sensational manner. This method creates a distracting emotional dominant (Batyuk, 2014).

Manipulation of information through technology is called coherent set of methods, techniques and means of manipulative influence, which aims to encouraging the subject to a predetermined address specific tasks. Quality use of technology allows manipulators get the planned result by forming in the team most suitable for them an economic acting and active algorithms.

There are many other different methods in the arsenal of manipulators. However, considering the manipulation, we must bear in mind that manipulative techniques can be applied not only consciously, that is, with some «ominous» purposes, but also quite inadvertently.

It is clearly that it is no need to re-evaluate the possibility of manipulative influence. Most people have very strong defense mechanisms. According to research from social psychology (Lazebna, 2011), the pressure manipulative influence can change only acquired in adulthood quality and belief, not fundamental and personal qualities, but also detraction is not worth from the effectiveness of manipulation.

Successful manipulation of information is that in most cases, do not want to waste emotional and mental strength, and time to have a doubt in actual material. Much of this is because passive dip in the stream of messages is much easier than to critically consider each of them and find the truth. On it a person will have forces, if it does not own to automatically the set of supervisory «mental cognitive tools» which by itself, without efforts of consciousness and desire, analyse information at subconscious level on one sign, that whether is the symptoms of manipulation.

Management is the result of mental, psychological, creative activities of a director, product of management work, and its adoption - a process that causes the appearance of the product. For successful fight against misinformation the head needs: a) to distinguish between facts, opinions and find out whether the informant is able to post its access to the communicated facts; b) to take into account subjective (arrogance, fantasy) and the characteristics of the source and its relation to the intended message; c) to use duplicate channels of information; d) to eliminate all unnecessary or intermediate links; d) to remember that especially easily is misinformation that is expected or received for the desired result.

\section{Conclusions}

Consequently, the management in terms of manipulation of information is a creative process of selecting from the list of possible alternatives to a single decision that is taken for executive action. Therefore, management decisions are characterized by the diversity and complexity of the interrelations of social, economic, political and technical factors in presenting information, so the main role in finding optimal and acceptable solution belongs to the head.

Specifics of management in terms of manipulation of information and uncertainty is that it is always an act of volition, social action, which expresses not only the needs and interests of individuals and reflects the interests of the organization, but also can realize the interests of the team as a whole that would not violate the etiquette and were accepted norms of human life.

\section{References}

Borovs 'ka, K. (2012). Manipulyator chy' aktualizator vy`bir za vamy`. K. Borovs'ka. Rezhy'm dostupu: http:www.business-territory.com/articles/man-za-vami (in Ukrainian).

Batyuk, B.B. (2014). Pidvy`shhennya efekty`vnosti upravlins`ky`x rishen` $\mathrm{V}$ agrarnomu sektori nacional'noyi ekonomiky`: teoriya, metodologiya, prakty`ka: [Monografiya]. L`viv (in Ukrainian).

Bern, E. (2003). Ljudi kotorye igrajut v igry. M.: JeksmoPress (in Russian).

Jellis, A. (2002). Gumanisticheskaja psihoterapija: Racional'no-jemocional'nyj podhod . M.: Izd-vo Jeksmo-Press (in Russian).

Kulinich, I.O. (2006). Psy`xologiya upravlinnya: psy`xologichny’j mexanizm pry`jnyattya rishen`. Elektronny`j resurs]. Rezhy`m dostupu: http:www.pidruchniki.ws/10810806 (in Ukrainian).

Lazebna, O. (2011). Specy`fika pry`jnyattya upravlins 'ky`x rishen` za umov nevy`znachenosti ta ry`zy`ku. [Elektronny`j resurs]. Rezhy`m dostupu: http:www.conf-cv.at.ua/forum/53-474-1

\section{(in} Ukrainian).

Frankl, V. (2015). Chelovek v poiskah smysla. M.: Progress (in Russian).

Palexa, Yu.I. (2006). Klyuchi do uspixu abo organizacijna ta upravlins'ka kul'tura. K.: Yevropejs'kogo universy`tetu (in Ukrainian). 
Perlz, F., Gudmen, P., Xefferly`n, R. (1995). Vnutri i vne pomojnogo vedra [Tekst]. SPb.: XXI vek (in Russian).

Petruni, Yu.Ye. (2011). Pry`jnyattya upravlins`ky`x rishen'. K.: CzUL (in Ukrainian).

Sidorenko, E.V. (2002). Trening vlijanija i protivostojanija vlijaniju. SPb.: Rech' (in Russian).

Cy`mbalyuk, V.S. (2009). Manipulyaciya informaciyeyu v upravlinni suspil'noyu dumkoyu ta vidobrazhennya yiyi $\mathrm{u}$ informacijnomu pravi. [Elektronny`j resurs].
Rezhy`m dostupu: http:www.khai.edu/csp/ nauchporta.pdf (in Ukrainian).

Shejnov, V.P. (2003). Skrytoe upravlenie chelovekom: Psihologija manipulirovanija. M.: Harvest (in Russian).

Shostrom, Je. (2003). Chelovek - manipuljator. M.: Izdvo Jeksmo-Press (in Russian).

Shulskyi, M.H. (2016). Tekhnolohii manipuliuvannia v upravlinskii diialnosti kerivnyka. Lviv, LNUVMtaBT (in Ukrainian).

Стаття надійшла до редакції 10.02.2017 